\title{
MENINGKATKAN KEMAMPUAN MEMBACA MELALUI MEDIA GAMBAR DAN KARTU KATA SISWAKELAS 1-B SD NEGERI 101800 DELITUA KABUPATENDELI SERDANG
}

\author{
Sri Gusmiati \\ Guru SD Negeri 101800 Delitua \\ Surel : sri_gurmati@gmail.com
}

\begin{abstract}
Abstrak
Penelitian ini bertujuan untuk mengetahui apakah kemampuan membaca siswa seperti dengan menggunakan media gambar dan kartu kata siswa dapat meningkatkan kemampuan membaca melalui penerapan media gambar dan kartu kata siswa pada mata pelajaran Bahasa Indonesia kelas 1-B di SD Negeri 101800 Delitua tahun pelajaran 2014/2015. Subjek penelitian ini adalah siswa kelas 1 SD Negeri 101800 Delitua dengan jumlah siswa 30 orang terdiri dari 13 siswa laki-laki dan 17 siswa perempuan. Dari penelitian yang dilaksanakan diperoleh peningkatan kemampuan membaca setelah dilaksanakan tindakan. Hasil penelitian pada saat pre-test, rata-rata kelas yang diperoleh siswa sebanyak dari 30 orang siswa, dimana 20 siswa memperoleh ketuntasan dan 10 siswa belum tuntas. Pada siklus I rata-rata siswa meningkat menjadi 27 siswa memperoleh ketuntasan dan 5 siswa belum tuntas.Pada siklus II rata-rata siswa meningkat dimana semua siswa memperoleh ketuntasan, dan observasi aktivitas siswa penilaian baik.
\end{abstract}

Kata Kunci : Media, Gambar, Kartu Kata

\section{PENDAHULUAN}

Pendidikan adalah untuk memberikan bekal kepada siswa agar dapat menyesuaikan kepada kehidupan masyarakat. Dalam kegiatan pembelajaran Bahasa Indonesia pada siswa sekolah dasar dapat dimulai dengan memperkenalkan gambar-gambar yang berhubungan dengan kehidupan sehari-hari.

Dalam pembelajaran Bahasa Indonesia siswa merasa kesulitan memahami jenis materi tertentu yang menyebabkan dalam pembelajaran kurang tercapainya suatu kompetensi dasar yang seharusnya itu merupakan satu tujuan yang diinginkan oleh guru. Bila pembelajaran Bahasa
Indonesia hanya di dominasi dengan metode ceramah dan belum menerapkan media pembelajaran maka mata pelajaran Bahasa Indonesia dapat menjadi mata pelajaran yang membosankan bagi siswa, karena mereka tidak secara langsung mengetahui dari apa yang di dengarnya dan di bacanya sehingga menyebabkan antara siswa dan pendidik tidak terjadi interaksi yang aktif, bertukar informasi, bicara dan mengemukakan pendapat serta membaca dengan baik.

Kemampuan membaca siswa masih rendah dilihat dari nilai rata-rata $(61 \%)$. selanjutnya dapat diketahui pada saat pembelajaran berlangsung dengan diamati dari bagaimana aktivitas siswa 
saat mengikuti pembelajaran, interaksi antar guru siswa, interaksi antar siswa dan motivasi belajar siswa. pembelajaran masih penulis lakukan belum menggunakan media pembelajaran sehingga sebagian besar masih pasif dan pembelajaran hanya berpusat pada guru. Hal itu menunjukkan kemampuan membaca siswa masih rendah dan perlu ditingkatkan lagi untuk meningkatkan pengetahuan siswa. Peningkatan kemampuan membaca siswa harus dilakukan dengan cara yang tidak menoton dimana berdampak sempitnya pemikiran siswa terhadap informasi yang diketahui.

$\begin{array}{cll}\text { Bicara tentang } & \text { pentingnya } \\ \text { kemampuan } & \text { membaca adalah : }\end{array}$

(1)Membaca membangun pondasi yang kuat untuk dapat mempelajari dan memahami berbagai disiplin ilmu sekaligus mengaplikasikan dalam kehidupan sehari-hari; (2)Senang membaca meningkatkan kecerdasan verbal dan lingusitik karena membaca memperkaya kosa kata dan kekuatan kata-kata; (3)Membaca mencegah rabun mata, karena membaca melatih dan mengaktifkan otot-otot mata; (4)Membaca mencegah kepikunan karena melibatkan tingkat konsentrasi lebih besar,mengaktifkan, dan menyegarkan pikiran; (5)Kegemaran membaca membantu meningkatkan kecerdasan, serta meningkatkan daya kreativitas dan imajinasi; (6)Membaca membantu memperbaiki rasa percaya diri, mengembangkan kemampuan memanajemen emosi, dan meningkatkan kemampuan melakukan interaksi sosial positif di mana pun dan kapan pun.

Materi Bahasa Indonesia tidak selalu dapat kita pelajari secara langsung.Halhal yang tidak dapat diamati dan dipelajari sesuai dengan keadaan aslinya sehingga memerlukan alat atau perantara sebagai media.Kelas dapat dijadikan sumber pembelajaran yang bisa dimanfaatkan guru dalam melaksanakan perannya sebagai pengelola kelas.

Media gambar dan kartu kata dalam pembelajaran merupakan sumber pembelajaran yang dapat membantu guru dalam melaksanakan perannya sebagai pendidik. Manfaat media gambar dan kartu kata adalah mengurangi kebosanan siswa, memusatkan perhatian siswa, mudah diingat, membantu pemahaman siswa serta mendorong untuk melakukan diskusi.Memanfaatkan lingkungan sebagai sumber pembelajaran mendorong siswa untuk berfikir logis.

Dan membangkitkan rasa ingin tahunya tentang topik yang akan diajarkan dengan melalui suatu pertanyaan yang dilanjutkan dengan kegiatan mencocokkan gambar yang ada. Misalnya siswa diberi pertanyaan tentang jenis gambar binatang atau tumbuhan kemudian siswa mencoba menjawab dengan gambar yang ada. Pada tahap ini siswa akan berpikir mengenai jawaban yang sesuai dari pertanyaan dengan mempehatikan gambar-gambar yang ada. Secara bergantian siswa mendengarkan pertanyaan dari guru dan berusaha mencari jawaban sesuai dengan gambar yang tersedia.

Dengan demikian siswa diharapkan dapat berperan aktif dalam proses pembelajaran, menghubungkan pertanyaan dengan gambar yang ada dan mengaitkan penjelasan yang ada. Sehingga dalam penelitian ini oleh penulis diberi judul "meningkatkan kemampuan membaca melalui penerapan media gambar dan kartu kata 
siswa kelas I-B SDN 101800 DELITUA KABUPATEN DELI SERDANG.

Pengajaran yang dilakukan selama dalam proses pembelajaran Bahasa Indonesia sebagian besar masih mengunakan :

a. Metode ceramah, dimana siswa yang hanya duduk dan mendengarkan tanpa adanya umpan balik lisan yang dilakukan siswa,

b. Menjadikan siswa bersikap pasif.

c. Tidak dapat mengembangkan pengetahuan yang dimiliki.

d. Pemberian materi yang pengajaran yang tidak runtut yang disebabkan guru kurang menguasai materi yang diajarkan, dan selama dalam proses pembelajaran media yang digunakan hanya papan tulis.

Masalah yang akan diberikan penyelesaiannya dalam penelitian ini dapat dirumuskan sebagai berikut :

a. Bagaimanakah menerapkan media gambar untuk meningkatkan minat belajar siswa mengenai kemampuan membaca melalui penerapan media gambar dan kartu kata siswa kelas I-B SDN 101800 Deli Tua kabupaten Deli Serdang.

b. Bagaimanakah upaya yang dilakukan pendidik untuk meningkatkan minat belajar siswa mengenai kemampuan membaca melalui penerapan media gambar dan kartu kata siswa kelas I-B SDN 101800 Deli Tua kabupaten Deli Serdang.
Adapun rumusan masalah penelitian ini yaitu apakah penerapan media gambar dan kartu kata dapat meningkatkan kemampuan membaca siswa kelas I-B SD Negeri 101800 Deli Tua. Sesuai dengan rumusan masalah penelitian tujuan penelitian ini adalah untuk :

a. Meningkatkan kemampuan membaca melalui penerapan media gambar dan kartu kata siswa kelas I-B SDN 101800 Deli Tua kabupaten Deli Serdang.

Manfaat yang diharapkan adalah sebagai berikut :

a. Bagi Guru

Hasil penelitian ini dapat dijadikan sebagai masukan untuk meningkatkan proses pembelajaran di kelas.

b. Bagi Peneliti

Hasil penelitian dapat dijadikan acuan dalam melakukan penelitian yang sejenis.

c. Bagi Kepala Sekolah

Hasil penelitian ini dapat dijadikan acuan dalam membuat kebijakan tentang peningkatan kualitas sekolah.

\section{METODOLOGI PENELITIAN}

Penelitian ini dilakukan di SD Negeri 101800 Delitua Jalan Lintas Sumatera Medan, Kecamatan Delitua, dan pelaksanaannya pada bulan Maret samapi dengan Juli 2015. 
Subjek dalam penelitian ini adalah seluruh siswa kelas I SD Negeri 101800 Delitua.Pemilihan kelas I dikarenakan peneliti merupakan guru kelas I SD Negeri 101800 Delitua.Banyak subjek penelitian yakni 30 orang siswa.

Alat pengumpulan data dalam penelitian ini antara lain :

\section{a. Tes hasil membaca}

Tes kemampuan membaca digunakan untuk mengetahui kemampuan membaca siswa sebelum dan sesudah pembelajaran dengan model media gambar dan kartu kata.

Tes kemampuan membaca disesuaikan dengan aspek penilaian membaca yaitu : lafal yang tepat, vocal, dan pemahaman yang mengacu pada KTSP untuk kelas I SD Negeri 101800 Delitua bidang studi Bahasa Indonesia.

Adapun aspek penilaian membaca sebagai berikut : aspek lafal, aspek vocal, dan aspek pemahaman, sebagai berikut :

\section{Lembar Aktifitas Belajar Siswa}

Lembar aktifitas belajar siswa digunakan oleh pengamat.Pengamat adalah guru-guru teman sejawat peneliti yaitu ibu muliatin dan ibu mirna waktu bekerja dalam kelompok peneliti/guru yang sedang melaksanakan kegiatan bekajar mengajar (KBM) memberi isyarat kepada dua pengamat, kelompok mana yang diamati oleh kedua

\begin{tabular}{|r|l|l|l|l|l|}
\hline \multicolumn{1}{|c|}{$\begin{array}{l}\text { N } \\
\mathbf{O}\end{array}$} & NAMA & \multicolumn{3}{|c|}{ ASPEK PENILAIAN } & \multirow{2}{*}{ SKOR } \\
\cline { 3 - 5 } & & LAFAL & VOKAL & PEMAHAMAN & \\
\hline 1 & & & & & \\
\hline 2 & & & & & \\
\hline 3 & & & & & \\
\hline 4 & & & & & \\
\hline 5 & & & & & \\
\hline 6 & & & & & \\
\hline 7 & & & & & \\
\hline 8 & & & & & \\
\hline 9 & & & & & \\
\hline 10 & & & & & \\
\hline
\end{tabular}

pengamat.Kedua pengamat tidak boleh duduk berdekatan agar data yang direkam tidak bias.Satu kali kegiatan pembelajaran yang dilakukan oleh peneliti maka ada dua kelompok yang diamati oleh pengamat.

Instrument aktifitas belajar siswa terdiri dari 5 aktifitas antara lain : membaca, bekerja, bertanya sesama siswa, bertanya sama guru, dan yang tidak relevan dengan KBM.

\section{Rancangan Penelitian.}

Penelitian ini menggunakan Penelitian Tindakan Kelas (PTK). Menurut Tim Pelatih Proyek PGSM, PTK merupakan suatu bentuk kajian yang bersifat reflektif oleh pelaku tindakan yang dilakukan untuk meningkatkan kemantapan rasional dari tindakan mereka dalam melaksanakan tugas, memperdalam pemahaman terhadap tindakantindakan yang dilakukan itu, serta memperbaiki kondisi dimana praktek pembelajaran tersebut dilakukan (Mukhlis, 2003:3)

Sesuai dengan jenis penelitian yang dipilih, yaitu penelitian tindakan kelas, maka 
penelitian ini menggunakan model penelitian tindakan dari Kemmis dan Taggart (Sugiarti, 1997:6), yaitu bentuk spiral dari siklus yang satu ke siklus berikutnya.Setiap siklus meliputi planning (rencana), action (tindakan), observation (pengamatan), reflection (refleksi).Langkah pada siklus berikutnya adalah perencanaan yang sudah direvisi, tindakan, pengamatan, dan refleksi.Sebelum masuk pada siklus I dilakukan tindakan pendahuluan yang berupa identifikasi permasalahan. Siklus spiral dari tahap-tahap penelitian tindakan kelas dapat dilihat pada gambar berikut :
Gambar : Penelitian Tindakan Model Kemmis dan Mc Taggart (Tim Pelatih Proyek PGSM, 1999 : 27)

\section{Prosedur Penelitian}

Berdasarkan informasi yang peneliti kumpulkan, bahwa hasil belajar siswa pada mata pelajaran Bahasa Indonesia masih rendah yang diakibatkan rendahnya aktifitas siswa, maka prosedur penelitian yang penulis rencanakan dalam menuntaskan hasil membaca tersebut adalah sebagi berikut :

\section{A. SIKLUS I}

Kegiatan/tahapannya pada siklus 1 meliputi :

\section{Perencanaan Tindakan}

Pada tahap ini peneliti membuat kegiatan perencanaan meliputi :

a. Penyusunan rencana pelaksanaan pembelajaran dalam lembar kegiatan siswa untuk KBM 1 dan KBM 2. Selanjutnya diubah atau ditambah sesuai dengan model pembelajaran media gambar dan kartu kata siswa.

b. Penyusunan instrument penelitian berupa lembar observasi aktifitas siswa melalui penerapan model pembelajaran media gambar dan kartu kata siswa dan tes pemahaman siswa.

a) Pelaksanaan Tindakan dan Observasi

Melaksanakan tindakan pembelajaran ke-1 dan ke-2 sesuai dengan RPP oleh penelitian sebagai guru Bahasa Indonesia dikelas I SD Negeri 101800 Delitua. Selama proses pembelajaran dilakukan observasi oleh observer (guru sejawat) untuk mengamati 
aktifitas siswa dan pengelolaan pembelajaran oleh guru. Diakhir siklus I dilakukan pula tes hasil membaca siswa sebagai formatif I.

b) Refleksi

Kegiatan refleksi dilakukan oleh peneliti berdasarkan hasil observasi dan evaluasi hasil pembelajaran bahasa Indonesia dengan model pembelajaran media gambar. Hassil dari refleksi kemudian peneliti dengan dua orang pengamat teman sejawat untuk memperbaiki dan menguatkan rencana tindakan siklus II.

\section{B. SIKLUS II}

Kegiatan pada siklus II meliputi :

a. Perencanaan Tindakan

Berdasarkan hasiL refleksi terhadap proses pembelajaran pada siklus I maka pada siklus II disusun sKenario model pembelajaran media gambar dan kartu kata siswa dengan revisi tidakan untuk memperbaiki proses. Peneliti berdiskusi secara kolaboratif dengan rekan guru kelas sejenis dengan kegiatan perencanaan meliputi :

a) Penyusunan rencana pelaksanaan pembelajaran dan lembar kegiatan siswa.

b) Penyusunan instrument penelitian berupa lembar observasi aktifitas siswa serta pengelolaan guru terhadap proses pembelajaran media gambar dan kartu kata siswa dan tes pemahaman siswa dalam kegiatan pembelajaran.

b. Pelaksanaan tindakan dan observasi Melaksanakan tindakan pembelajaran ke-3 dan ke-4 sesuai dengan RPP strategi media gambar dan kartu kata siswa oleh penelitian sebagai guru Bahasa Indonesia dikelas I SD Negeri 101800 Delitua. Selama proses pembelajaran dilakukan observasi oleh observer (guru sejawat) untuk menagmati aktifitas siswa dan pengelolaan pembelajaran oleh guru. Diakhir siklus II dilakukan pula tes hasil membaca siswa untuk mengetahui pemahaman kognitif siswa sebagai formatif II.

c. Refleksi

Setelah kegiatan pembelajaran siklus II dilaksanakan, dilanjutkan dengan kegiatan refleksi oleh peneliti berkolaborasi guru mata pelajaran sejenis.Berdasarkan hasil observasi aktifitas siswa dalam pembelajaran dan ketuntasan hasil membaca siswa ditelaah.

\section{Teknik Analis Data}

Metode analis data pada penelitian ini digunakan metode deskriptif dengan membandingkan hasil membaca siswa setelah tindakan.

Langkah-langkah pengolahan data sebagai berikut :

a. Merekapitulasi nilai pretes sebelum tindakan dan nilai tes akhir siklus I dan siklus II

b. Menghitung nilai rata-rata atau persentase hasil membaca siswa sebelum dan setelah dilakukan tindakan pada siklus I dan siklus II untuk mengetahui adanya peningkatan hasil membaca.

c. Penilaian

a) data nilai hasil belajar (kognitif) diperoleh dengan menggunakan rumus : 
Nilai Siswa
$\frac{\text { jumlah jawaban benar }}{\text { jumlah Seluruh soal }} \times 100$

(Slameto, 2001:189)

b) Nilai rata-rata siswa dicari dengan rumus sebagai berikut:

$$
X=\frac{\sum \mathrm{X}}{N}
$$

(Subino,

1987:80)

Keterangan :

$\mathrm{X}=$ Nilai rata-rata

$\Sigma=$ Jumlah Nilai $\mathrm{X}$

$\mathrm{N}=$ Jumlah Peserta Tes

c) untuk penilaian aktivitas digunakan rumus sebagai berikut :

Setelah data aktivitas siswa terkumpul sesuai dengan jumlah kegiatan belajar mengajar, maka data tersebut disusun kemudian data tersebut dirubah menjadi data prosentase.Untuk menganalisis data-data tersebut kemudian dianalisis dengan proporsi aktivitas.

$\%$

Proporsi

Aktivitas $=$

$\frac{\text { jumlah skor yang diperole }}{\text { jumlah skor ideal }} \times 100 \%$

Ketuntasan b(Majid, 2009:268)

d. ketentuan persentase elajar kelas

Ketentuan belajar kelas $=\frac{\sum \mathrm{S} \mathrm{b}}{K} \times 100 \%$

$\sum \mathrm{Sb}=$ Jumlah siswa yang mendapat nilai $\geq 70$ (kognitif)

$\sum \mathrm{K}=$ Jumlah siswa dalam mapel
Sebagai tolak ukur keberhasilan penelitian tindakan kelas ini dapat di lihat dari hasil tes, jika hasil belajar siswa mencapai nilai $\geq 70$ maka disebut tuntas individu, dan bila ada $85 \%$ nilai $\geq 70$ disebut tuntuas kelas.

\section{Indikator Keberhasilan}

Yang menjadi indikator keberhasilan guru mengajar digunakan KKM mata pelajaran Bahasa Indonesia di SDN 010800 Delitua dengannilai $\geq 70$ maka disebut tuntas individu, dan bila ada $85 \%$ nilai $\geq 70$ disebut tuntuas kelas.

\section{HASIL PENELITIAN DAN PEMBAHASAN}

Sekolah Dasar Negeri 101800 Delitua kecamatan Delitua kabupaten Deliserdang.Kurikulum yang diterapkan selama pengambilan data di SD Negeri 101800 Delitua adalah kurikulum tingkat satuan pendidikan (KTSP).KTSP merupakan sebuah kurikulum yang dibuat oleh sekolah yang melibatkan unsure kepala sekolah, pembantu kepala sekolah, guru, dan komite sekolah.

Siswa-siswa SD Negeri 101800 Delitua berasal dari daerah desa Delitua dan sekitarnya. Umumnya siswa berasal dari keluarga yang orang tuanya berprofesi sebagai bangunan,

Kondisi ini berimplikasi pada pembelajaran, dimana sebagian besar siswa tampak kurang memperhatikan penjelasan dari guru, kurang 
memberikan respon terhadap pertanyaan dan penjelasan dari guru, siswa juga mengeluh terhadap tugas yang diberikan oleh guru, siswa tidak langsung mengerjakan tugas yang diberikan guru, tidak tepat waktu mengumpulkan tugas, serta siswa kurang senang terhadap mata pelajaran bahasa Indonesia.

\section{Hasil Membaca Siswa}

Data Postes I

Data postes ini menujukan bahwa siswa tidak mempersiapkan diri belajar dirumah sebelum mempelajari materi baru yang akan disampaikan guru disekolah sekaligus dapat disimpulkan bahwa motivasi dan kemandirian siswa sangat rendah.

Merujuk pada kesimpulan ini guru sebagi peneliti berusah memperbaiki proses dan hasil membaca siswa dengan menerapkan model pembelajaran media gambar dan kartu kata siswa.

Hasil belajar yang diperoleh pada siklus I selama dua pertemuan disajikan sebagai berikut :

Distribusi data protes I

\begin{tabular}{|c|c|c|}
\hline Nilai & Frekuensi & Rata-Rata \\
\hline 50 & 11 & \multirow{4}{*}{61} \\
\hline 60 & 5 & \\
\hline 65 & 6 & \\
\hline 70 & 8 & \\
\hline
\end{tabular}

Data hasil belajar dealam table diatas dapat dilihat dalam diagram histogram seperti sebagai

berikut :

\section{Persentase Kemampuan Membaca siswa siklus I}

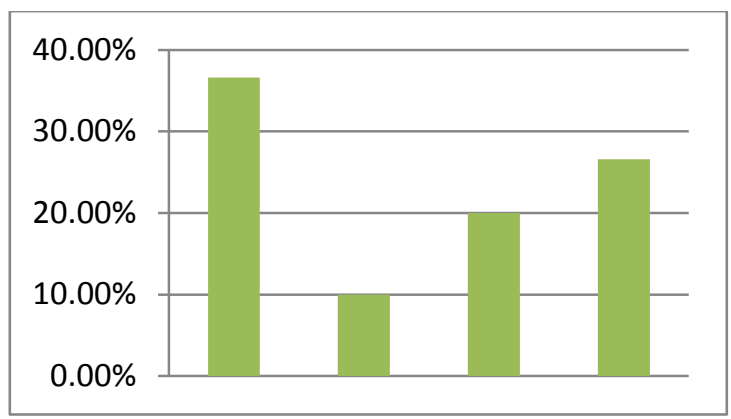

Kegiatan/tahapannya pada siklus 1 meliputi :

\section{A. Perencanaan Tindakan}

Pada tahap ini peneliti membuat kegiatan perencanaan meliputi :

a. Penyusunan rencana pelaksanaan pembelajaran dalam lembar kegiatan siswa untuk KBM 1 dan KBM 2. Selanjutnya diubah atau ditambah sesuai dengan model pembelajaran media gambar dan kartu kata siswa.

b. Penyusunan instrument penelitian berupa lembar observasi aktifitas siswa melalui penerapan model pembelajaran media gambar dan kartu kata siswa dan tes pemahaman siswa.

B. Pelaksanaan Tindakan dan Observasi

Melaksanakan tindakan pembelajaran ke-1 dan ke-2 sesuai dengan RPP oleh penelitian sebagai guru Bahasa Indonesia dikelas I SD Negeri 101800 Delitua. Selama proses 
pembelajaran dilakukan observasi oleh observer (guru sejawat) untuk mengamati aktifitas siswa dan pengelolaan pembelajaran oleh guru. Diakhir siklus I dilakukan pula tes hasil membaca siswa sebagai formatif I.

\section{Refleksi}

Kegiatan refleksi dilakukan oleh peneliti berdasarkan hasil observasi dan evaluasi hasil pembelajaran bahasa Indonesia dengan model pembelajaran media gambar. Hassil dari refleksi kemudian peneliti dengan dua orang pengamat teman sejawat untuk memperbaiki dan menguatkan rencana tindakan siklus II.

\section{Data Postes II}

Setelah melakukan beberapa tindakan perbaikan pembelajaran pada siklus ii maka dilakukan tes pada siklus ii sebagai postes ii. Data postes ii disajikan :

Distribusi data postes II

\begin{tabular}{|c|c|c|}
\hline Nilai & Frekuensi & Rata-Rata \\
\hline 60 & 5 & \multirow{2}{*}{83.3} \\
\cline { 1 - 2 } 80 & 15 & \\
\hline 100 & 10 & \\
\hline
\end{tabular}

\author{
Dalam hasil postes II ini \\ dapat disajikan kembali dalam \\ bentuk grafik histogram seperti \\ beriku :
}

\section{Persentase kemampuan membaca siswa siklus II}

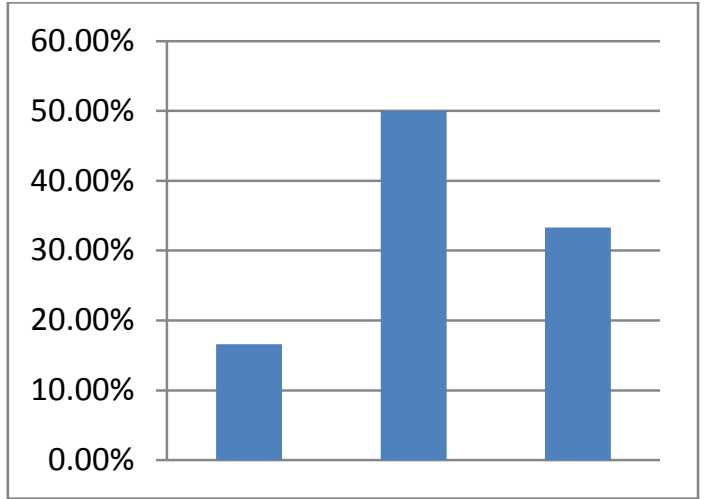

Kegiatan pada siklus II meliputi

a. Perencanaan Tindakan

Berdasarkan hasiL refleksi terhadap proses pembelajaran pada siklus I maka pada siklus II disusun sKenario model pembelajaran media gambar dan kartu kata siswa dengan revisi tidakan untuk memperbaiki proses. Peneliti berdiskusi secara kolaboratif dengan rekan guru kelas sejenis dengan kegiatan perencanaan meliputi :

a) Penyusunan rencana pelaksanaan pembelajaran dan lembar kegiatan siswa.

b) Penyusunan instrument penelitian berupa lembar observasi aktifitas siswa serta pengelolaan guru terhadap proses pembelajaran media gambar dan kartu kata siswa dan tes pemahaman siswa dalam kegiatan pembelajaran.

b. Pelaksanaan tindakan dan observasi Melaksanakan tindakan pembelajaran ke-3 dan ke-4 sesuai dengan RPP strategi media gambar dan kartu kata siswa oleh penelitian sebagai guru Bahasa Indonesia dikelas I SD Negeri 101800 Delitua. Selama proses pembelajaran dilakukan observasi oleh observer (guru sejawat) untuk 
menagmati aktifitas siswa dan pengelolaan pembelajaran oleh guru. Diakhir siklus II dilakukan pula tes hasil membaca siswa untuk mengetahui pemahaman kognitif siswa sebagai formatif II.

c. Refleksi

Setelah kegiatan pembelajaran siklus II dilaksanakan, dilanjutkan dengan kegiatan refleksi oleh peneliti berkolaborasi guru mata pelajaran sejenis.Berdasarkan hasil observasi aktifitas siswa dalam pembelajaran dan ketuntasan hasil membaca siswa ditelaah.

\section{Pembahasan}

Setelah dilakukan pembelajaran yang berimplementasi kurikulum berbasis kompetensi, diperoleh perubahan baik suasana kelas maupun kemampuan siswa dalam menyelesaikan lks dan tes hasil membaca, hal ini dikarenakan dalam setiap proses pembelajaran yang dilakukan dalam penelitian ini mencakup komponen-komponen yang terdapat dalam media gambar dan kartu kata siswa, yaitu konstruktivisme, inquiry, questioning, learning community, modeling, reflection, dan authentic assessment.

pada mata pelajaran bahasa Indonesia dalam menyelesaikan tes akhir siklus, diperoleh rata-rata nilai siswa pada siklus I adala $\mathrm{h} 61 \%$ dengan jumlah siswa yang tuntas atau mencapai nilai 70 adalah 8 siswa atau 26,6 \% dari 30 siswa. Diperoleh pada siklus II rata-rata nilai tes yang diperolej jauh lebih baik dari tes I yaitu $83,3 \%$.

\section{SIMPULAN DAN SARAN}

\section{Simpulan}

a. hasil membaca siswa dengan menerapkan model pembelajaran media gmabr dan kartu kata siswa pada mata pelajaran bahasa Indonesia kelas I-B SD Negeri 1010800 Delitua tahun pembelajaran 2014/2015, diketahui pada postes I diketahui rata-rata 61 dan postes II dengan rata-rata 83,3 dengan kesipulan hasil terus meningkat .

b. aktifitas membaca siswa dengan menerapkan model pembelajaran media gambar dan kartu kata siswa pada siklus I dan siklus II berdasarkan pengamatan kedua observer adalah : pengamatan siklus I, membaca $36 \%$, bekerja $22 \%$, bertanya pada teman $12 \%$, bertanya pada guru $13 \%$, dan tidak relevan dengan KBM 17\%. Pengamat siklus II, membaca $25 \%$, bekerja $37 \%$, bertanya pada teman $23 \%$, bertanya pada guru $10 \%$, dan tidak relevan dengan KBM 5\%.

\section{Saran}

Setelah melakukan kegiatan pembelajaran dengan menerapkan model pembelajaran media gmabr dan kartu kata siswa pada mata pelajaran Bahasa Indonesia kelas I-B SD Negeri 1010800 Delitua.

Model pembelajaran media gambar dan kartu kata dapat diterapkan dengan sempurna dalam kelompok. 
1. Selama kerja kelompok aturanaturan di informasikan kepada siswa sesuai dengan tujuan pembelajaran.

2. Motivasi diberikan kepada awal pertemuan agar selama bekerja dalam kelompok aktifitas sisw lebih baik.

\section{DAFTAR RUJUKAN}

Aqib, Zainal. (2006).Penelitian

Tindakan Kelas. Bandung: Yrama Widya.

Dimyati, dan Mudjiono, 2006. Belajar dan Pembelajaran. Jakarta: PT RinekaCipta.

Djamarah, SyaifulBahri dan AswanZain. 2006. Startegi Belajar Mengajar. Jakarta: PT Rineka Cipta.

Lie, Anita. 2008. Cooperative learning.Jakarta : PT Gramedia Sagala, $\quad 2003$. KonsepdanMaknaPembelajara $n$. Bandung: CV Alfabeta.

Sardiman, A. M. (2006). Interaksi dan Motivasi Belajar Mengajar, Raja Grafindo Persada, Jakarta.

Sudjana, N. (2005). Penilaian Hasil Proses Mengajar, Penerbit. 